Theological Research • volume 6 (2018) - p. 71-85

doi: http://dx.doi.org/10.15633/thr.3524

DAMian WĄSEK

https://orcid.org/o0oo-0003-I349-I4II

Uniwersytet Papieski Jana Pawła II w Krakowie

Pawę GŁowacz

https://orcid.org/oooo-oooI-6324-I432

Uniwersytet Papieski Jana Pawła II w Krakowie

\title{
Rola biskupa w Kościele: pasterz czy tylko zarzadca? \\ Punkty sporne i perspektywy zmian
}

\begin{abstract}
The Role of Bishops in The Church: A Pastor or Only A Manager? Trouble Spots and Perspectives of A Change The article is an attempt to answer the question: Where is the pastoral dimension of religious service of bishops dominated by their managerial tasks and how may this be changed? Four of these modifications have been highlighted. Firstly, it is necessary to get away from the practice of the bishop's nomination, where is a place just for managers. I particularly have in mind the Roman Curia and Apostolic Nunciature. Secondly, we need to intensify a process of decentralization of competences in ecclesiastical structures - transferring a maximal number of rights from Rome to local churches. Thirdly, the pastoral function of bishops will be emphasized if there were not any auxiliary bishops but only one pastor in a diocese. Fourthly, it is necessary to improve the process of communication between bishops and lay people in the cases of canonical visitations and pastoral letters.
\end{abstract}

\section{KeYwORDs}

Papal primacy, bishop, reform of the church, decentralization, theological hermeneutic 
Kiedy obserwujemy współczesne spory teologiczne, wydaje się, że toczą się one między dwiema frakcjami o odmiennych priorytetach. $Z$ jednej strony widzimy środowisko zatroskane przede wszystkim o wierność Tradycji, dotychczasowym interpretacjom i orzeczeniom Magisterium Kościoła. Pewna grupa teologów utrzymuje, że hermeneutyka ciągłości powinna cechować każde rozwiązanie i argumentują, że ostatecznym kryterium dla przyjmowania nowych rozwiązań jest jak najwyższy stopień ich zgodności ze słowami wypowiedzianymi przez poprzedniego papieża czy inny autorytet kościelny. Po przeciwnej stronie wsłuchujemy się w stanowiska teologów bardzo wrażliwych na współczesność, dla których priorytetem jest wiarygodność katolicyzmu dzisiaj. Ich argumentacja koncentruje się na czynnikach socjologicznych, zmianach cywilizacyjnych i „pulsie” chrześcijan żyjących tu i teraz, a historyczne orzeczenia traktują oni bardzo kontekstualnie - jako „aptekę, w której tylko niektóre lekarstwa wciąż skutkują", więc trzeba z odwagą szukać lepszych rozwiązań, korzystając z nowych osiągnięć naukowych. Porozumienie jest możliwe tylko wtedy, gdy jedna i druga strona otworzy się na realny dialog, a taki wymaga wypracowania rozwiązań, które zachowają istotne elementy Tradycji, równocześnie umożliwiając otwarcie na nowe interpretacje, adekwatne do aktualnego stanu wiedzy o człowieku i świecie $e^{\mathrm{I}}$. Potrzeba takiego spojrzenia na zagadnienie posługi biskupa w Kościele jest przyczyną powstania poniższego tekstu.

Celem artykułu będzie prezentacja tych obszarów działalności biskupów, w których zadania zarządcze wydają się dominować nad pasterskimi oraz wskazanie kierunków zmian, które mogłyby przywrócić właściwe oblicze teologii episkopatu.

Problem zawiera się w pytaniu: Gdzie pasterski wymiar posługi biskupiej zszedł na dalszy plan i jak można by to zmienić?

Będzie to wizja przekraczająca w wielu miejscach aktualny stan w prawie kanonicznym, a czasem ramy narzucone przez współczesne interpre-

I W tym duchu wypowiedział się Jan Paweł il o poszukiwaniach nowych form sprawowania prymatu papieskiego: „Jestem przekonany, że ponoszę w tej dziedzinie szczególną odpowiedzialność, która polega przede wszystkim na dostrzeganiu ekumenicznych dążeń większości chrześcijańskich Wspólnot i na wsłuchiwaniu się w kierowaną do mnie prośbę, abym znalazł taką formę sprawowania prymatu, która nie odrzucając bynajmniej istotnych elementów tej misji, byłaby otwarta na nową sytuację" (Jan Paweł II, Ut Unum Sint, nr 95, https://opoka.org.pl/biblioteka/W/wP/jan_pawel_ii/encykliki/ ut_unum_2.html\#m3 (30.10.2017). 
tacje teologiczne. Nie należy czytać tego tekstu w kluczu poszukiwania nowej ortodoksji, ale raczej potraktować go jako propozycję budowania możliwej - moim zdaniem - strategii rozwoju struktur kościelnych.

$\mathrm{Z}$ uwagi na charakter zagadnienia posłużę się metodą syntetyczną, a w niektórych miejscach tekst będzie miał charakter eseju teologicznego ${ }^{2}$. Całość wpisze się w anzelmiańską metodę fides quaerens intellectum, czyli będzie krytycznym poszukiwaniem zrozumienia zastanych rozwiązań eklezjalnych, po to, by je uwiarygodnić.

Punkty sporne i perspektywy zmian w pełnieniu pasterskiej funkcji przez biskupów rozważę, poruszając się po trzech płaszczyznach. Najpierw zapytam o naturę posługi pasterskiej biskupów nieposiadających diecezji, później o relację między funkcją pasterską biskupa Kościoła lokalnego i Kościoła powszechnego, a w ostatniej części skupię się na relacjach pasterza $\mathrm{z}$ owczarnią $\mathrm{w}$ diecezji.

\section{Pasterze bez owCZarni}

W samej definicji pasterzowania ujęty jest element relacyjny - pasterz jest ustanowiony dla owczarni. Istnienie pasterzy bez owczarni wydaje się być nielogicznie i teologicznie nieuzasadnione, poza przypadkami pasterzy chorych lub emerytowanych. Myśląc w takiej perspektywie o przedmiocie tego artykułu, zastanawiam się nad udzielaniem sakry biskupiej pracownikom Kurii Rzymskiej i nuncjuszom apostolskim, ponieważ w tych przypadkach bardzo trudno uzasadnić pasterską naturę posługi biskupa, a sakra wydaje się być jedynie stopniem awansu w watykańskiej strukturze urzędniczej. Uzasadnieniem dla takich nominacji jest raczej proces zarządzania Kościołem. Szukając analogii, można śmiało stwierdzić, że udzielenie sakry biskupiej pracownikom w kongregacjach czy nuncjaturze jest tutaj tożsame $z$ mianowaniem ministra $w$ rządzie i staje się godnością budującą pozycję wewnątrzkościelną oraz podnoszącą

2 Systematyczne opracowanie naukowe zmian w zarządzaniu Kościołem zaproponowałem w książce Nowa wizja zarzqdzania Kościotem, Kraków 20I4 - zawiera ona pogłębioną refleksję teologiczną na poruszane w artykule tematy. Niektóre propozycje prezentowane w tym tekście były więc poruszone również w tamtej monografii, ale tutaj inaczej je systematyzuję, komentuję i szerzej oceniam. W dużej mierze artykuł jest też prezentacją nowych rozwiązań. 
rangę w procesie podejmowania i uzasadniania decyzji, prowadzenia różnych negocjacji i rozmów.

Rodzi to wiele problemów teologicznych, ale i praktycznych. Przykładowo, z kategorii tych drugich można wymienić komplikacje w procesie zmian w poszczególnych urzędach z biskupem na czele, ponieważ święcenia biskupie nie wygasają wraz z końcem kadencji. Osoba odchodząca ze stanowiska przechodzi więc na wcześniejszą emeryturę (np. kard. Gerhard Müller) albo szuka się dla niej diecezji, gdzie mogłaby zostać ordynariuszem, co niekoniecznie wiąże się z troską pasterską o „obdarowany” Kościół lokalny.

Uważam, że jedynym sposobem na uratowanie teologii biskupstwa na tym polu jest kategoryczny zakaz udzielania sakry biskupiej pracownikom urzędów kościelnych. Dla zbudowania prestiżu osób pełniących funkcje w Watykanie można używać tego samego tytułu, który funkcjonuje w świeckich rządach i mianować ich ministrami lub wymyślić jakiś nowy tytuł administracyjny. Poza eliminacją wspomnianych powyżej problemów praktycznych, takie rozwiązanie sprawiłoby także, że osoby świeckie pełniące wysokie stanowiska mogłyby być traktowane identycznie i cieszyć się podobnym szacunkiem,jaki posiadają duchowni szefowie dykasterii.

Na marginesie tej refleksji można zapytać, czy udział osób duchownych w strukturach Kurii Rzymskiej nie powinien być zredukowany do minimum? Można sobie wyobrazić, że poszczególne urzędy piastują kompetentne osoby świeckie, co mogłoby pomóc w funkcjonowaniu departamentów jako sekretariatów, a nie pionów władzy i szczebli kariery kościelnej.

\section{Relacja biskupa lokalnego z Rzymem}

W obecnie realizowanym modelu eklezjologicznym odpowiedzialność pasterska biskupa za Kościół lokalny wyraża się w inkulturacji pewnych przepisów centralnych, egzekwowaniu ich na poziomie lokalnym, interpretowaniu ich i doprecyzowywaniu $\mathrm{z}$ uwzględnieniem konkretnego kontekstu społecznego i kulturowego. $Z$ punktu widzenia pełnienia władzy pasterskiej biskup ordynariusz nie jest więc wikariuszem papieża, ale odpowiedzialnym za własną diecezję i współodpowiedzialnym za Kościól powszechny.W praktyce eklezjalnej wydaje się jednak, że w wielu środowiskach kościelnych wciąż dominuje przekonanie wywodzące się 
z czasów eklezjologii instytucjonalnej, wedle której rola ordynariusza w diecezji sprowadza się do powtarzania stanowiska Watykanu. Ten typ pasterzowania poparty jest licznymi procedurami kanonicznymi, wynikającymi z centralizacyjnej działalności Kurii Rzymskiej (której znaczenie $\mathrm{w}$ minionym wieku systematycznie rosło) i z podobnego podejścia wielu papieży.

Choć podczas obecnego pontyfikatu tempo reformowania urzędów watykańskich nie zadawala, wydaje się, że papież Franciszek jest pierwszym od dawna biskupem Rzymu troszczącym się o procesy decentralizacyjne, które powoli, ale jednak postępują. Zaznaczył to w programowym dokumencie Evangelii Gaudium, szczególnie w punkcie ı6: „Nie uważam także, że należy oczekiwać od papieskiego nauczania definitywnego lub wyczerpującego słowa na temat wszystkich spraw dotyczących Kościoła i świata. Nie jest rzeczą stosowną, żeby Papież zastępował lokalne Episkopaty w rozeznaniu wszystkich problemów wyłaniających się na ich terytoriach. W tym sensie dostrzegam potrzebę przyjęcia zbawiennej «decentralizacji»"3.

Określenie procesu dywersyfikacji odpowiedzialności w Kościele przymiotnikiem „zbawienny” już samo w sobie jest znamienne. Ilustracją wyżej cytowanych słów są nieliczne na razie inicjatywy. Poniżej wskazane zostaną dwa przykłady dowartościowania odpowiedzialności pasterskiej biskupa lokalnego:

a. Zgodnie z Amoris laetitia interpretacja szczegółowych wytycznych co do rozeznawania sytuacji osób żyjących w związkach niesakramentalnych pozostawiona jest biskupom lokalnym. W punkcie 300 . czytamy: „Biorąc pod uwagę niezliczoną różnorodność poszczególnych sytuacji $[\ldots]$, można zrozumieć, że nie należy oczekiwać od Synodu ani też od tej adhortacji nowych norm ogólnych typu kanonicznego, które można by stosować do wszystkich przypadków. Możliwa jest tylko nowa zachęta do odpowiedzialnego rozeznania osobistego i duszpasterskiego indywidualnych przypadków, które powinno uznać, że ponieważ «stopień odpowiedzialności nie jest równy w każdym przypadku», to konsekwencje lub skutki danej normy niekoniecznie muszą być takie same. Zadaniem kapłanów jest «towarzyszenie osobom zainteresowanym na drodze rozeznania,

3 Franciszek, Evangelii gaudium [dalej: EG], nr I6; https://w2.vatican.va/content/ francesco/pl/apost_exhortations/documents/papa-francesco_esortazione-ap_2OI3II24_ evangelii-gaudium.html (30.10.20I7). 
zgodnie z nauczaniem Kościoła i wytycznymi biskupa»"4. Z komentarzy i opracowań wynika, że papież podzielił się ogólnymi spostrzeżeniami, wskazał na konieczność zmiany w praktyce duszpasterskiej, a resztę - stworzenie regulacji wykonawczych - pozostawił biskupom miejsca. Uzasadnienia takiej postawy można szukać w punkcie 3. tej adhortacji, gdzie czytamy: „Przypominając, że «czas jest ważniejszy niż przestrzeń», pragnę podkreślić, iż nie wszystkie dyskusje doktrynalne, moralne czy duszpasterskie powinny być rozstrzygnięte interwencjami Magisterium. Oczywiście, w Kościele konieczna jest jedność doktryny i działania, ale to nie przeszkadza, by istniały różne sposoby interpretowania pewnych aspektów nauczania lub niektórych wynikających z niego konsekwencji. Będzie się tak działo, aż Duch nie doprowadzi nas do całej prawdy (por. J I6, I3), to znaczy, kiedy wprowadzi nas w pełni w tajemnicę Chrystusa i będziemy mogli widzieć wszystko Jego spojrzeniem. Poza tym, w każdym kraju lub regionie można szukać rozwiązań bardziej związanych z inkulturacją, wrażliwych na tradycje i na wyzwania lokalne. Ponieważ «kultury bardzo różnią się między sobą i każda ogólna zasada [...] potrzebuje inkulturacji, jeśli ma być przestrzegana i stosowana w życiu»"s. Za taką właśnie inkulturację tekstów redagowanych na poziomie centralnym odpowiedzialne są episkopaty lokalne. Niektórzy uważają, że jest to rozbijanie jedności Kościoła, ale wydaje się, że wnioski te wynikają z niezrozumienia intencji papieża i natury pasterskiej funkcji biskupa ordynariusza. Analiza tekstu Amoris laetitia prowadzi bowiem do wniosku, że biskupi lokalni nie zostali wezwani do wprowadzania orzeczeń doktrynalnych, a więc stwierdzenia, czy można czy nie rozeznawać przypadki w kierunku dopuszczenia do sakramentów taka interpretacja została uczyniona przez ojca świętego dla Kościoła powszechnego. Biskupi mają ułatwić duszpasterzom sam proces rozeznawania, sugerując właściwe specyfice miejsca akcenty w rozmowie duszpasterskiej i precyzując kształt procesu rozeznawania.

b. Dowartościowanie kompetencji pasterskich biskupów lokalnych widać również w motu proprio Magnum Principium. Wprowadzone tam zostały zmiany w ustępach 2 i 3 kanonu 838 kodeksu prawa

4 Franciszek, Amoris laetitia, nr 300, https://w2.vatican.va/content/francesco/ p1/apost_exhortations/documents/papa-francesco_esortazione-ap_20160319_amoris-laetitia.html (30.10.2017). Podkreślenia własne.

5 Franciszek, Amoris laetitia, nr 3. Podkreślenia własne. 
kanonicznego w zakresie odpowiedzialności za zatwierdzanie i publikowanie tekstów liturgicznych w językach narodowych ${ }^{6}$. Papież przeniósł część uprawnień z Kongregacji Kultu Bożego i Dyscypliny Sakramentów na konferencje episkopatów krajowych, by pokazać, że pasterska odpowiedzialność za Kościoły lokalne spoczywa przede wszystkim na ich pasterzach. W perspektywie długoletniej dominacji Kurii Rzymskiej znamienne były wypowiedzi prefekta Kongregacji ds. Kultu Bożego i Dyscypliny Sakramentów kard. Roberta Saraha, który - komentując Magnum Principium - podkreślał, że dokument papieski jednak nie zmienia uprawnień kongregacji, a więc nie zwalnia konferencji episkopatów krajowych z obowiązku przedłożenia do zatwierdzania przez tę dykasterię nowych tłumaczeń tekstów liturgicznych 7 . Hierarcha sugerował tym samym, że proces przeniesienia kompetencji w orzekanej materii nie postąpił tak daleko, jak chcieliby niektórzy komentatorzy. Prefekt kongregacji nie miał racji, a do sprostowania błędnej interpretacji kard. Saraha doprowadziła dopiero bezpośrednia interwencja papieża - list, w którym ojciec święty przedstawił właściwy, a więc decentralizujący wydźwięk komentowanego motu proprio ${ }^{8}$.

Niestety, opisane powyżej pozytywne rozwiązania stanowią zaledwie przyczynek do mówienia o prowadzeniu procesu decentralizacji w Kościele. Istnieje bardzo wiele obszarów dotyczących spraw Kościołów lokalnych, w których decydujący głos wciąż należy do rzymskich kongregacji. Sprawą kluczową, której chciałbym poświęcić więcej uwagi, jest procedura mianowania nowych biskupów. Wydaje się, że w tym zakresie centralizacja postąpiła bardzo daleko. Jeszcze w czasach Soboru Trydenckiego możliwe były trzy drogi wyborów - typowanie królewskie,

6 Por. Franciszek, Magnum principium, http://press.vatican.va/content/salastampa/ en/bollettino/pubblico/20I7/o9/o9/I709oga.html (30.I0.20I7).

7 Relację z wywiadu kard. R. Saraha przedstawił między innymi deon.pl. Por. Kard. Sarah: ttumaczenia ksiag liturgicznych nadal musza być zatwierdzone przez Rzym, https:// www.deon.pl/religia/kosciol-i-swiat/z-zycia-kosciola/art,31997,kard-sarah-tlumaczenia-ksiag-liturgicznych-nadal-musza-byc-zatwierdzone-przez-rzym.html?utm_source=deon\&utm_medium=link_artykul (30.10.20I7).

8 Por. Papież poprawia kard. Saraha. Zmiany liturgiczne sa gtębsze niż wskazywat hierarcha, https://www.deon.pl/religia/serwis-papieski/aktualnosci-papieskie/ art,630I,papiez-poprawia-kard-saraha-zmiany-liturgiczne-sa-glebsze-niz-wskazywal-hierarcha.html (30.10.20I7). 
papieska nominacja oraz wskazanie przez kapituły katedralne, przy czym druga $\mathrm{z}$ tych dróg zdawała się być marginalna jeszcze $\mathrm{w}$ drugiej połowie xIX wieku. Jak zaznaczył abp John Quinn, w I829 roku na 646 biskupów diecezjalnych w Kościele zachodnim, 555 było mianowanych przez władze państwowe, 67 przez kapituły katedralne, a tylko 24 bezpośrednio przez papieża. Później sytuacja zmieniała się diametralnie, a nominacje biskupie szybko traciły wymiar wydarzenia o charakterze eklezjalnym ${ }^{9}$.

Szukając podstaw do zmiany aktualnie dominującego modelu, można sięgać po świadectwa patrystyczne. Francuski jezuita Bernard Sesboüé przytoczył historie św. Cypriana czy Ambrożego, wskazując na znaczący udział wiernych w tych procedurach. W czasach wspomnianych ojców Kościoła rola biskupów z danego regionu ograniczała się do akceptacji głosu wiernych wakującej diecezji, sprawdzenia, czy kandydatura zaproponowana przez lud jest zgodna z obowiązującymi kanonami Kościoła, i udzielenie święceń ${ }^{\text {Io }}$. Nie wymagano żadnych konsultacji z biskupem Rzymu. Podobnie papież Grzegorz Wielki szanował tradycję kanoniczą, zgodnie z którą wspólnota musiała się zgodzić bądź przynajmniej nie sprzeciwiać ustanowieniu kogoś jej ordynariuszem ${ }^{\text {II }}$. Jak jest dzisiaj? Możliwość konsultacji kandydatur na biskupów w myśl aktualnego kodeksu prawa kanonicznego ${ }^{\mathrm{I} 2}$ nie jest realną decentralizacją tego procesu, ponieważ przedstawiciele wspólnot lokalnych w najmniejszym nawet stopniu nie posiadają głosu decyzyjnego: redagowanie listy nazwisk pozostaje w gestii urzędnika papieskiego, a ostateczna decyzja w rękach biskupa Rzymu, który jest tak dalece wolny w nominowaniu, że nie musi się nawet tą listą sugerowaćr ${ }^{13}$.

$Z$ rozsądną - moim zdaniem - propozycją modyfikacji tych procedur wystąpiło w 1973 roku profesjonalne stowarzyszenie prawników The Canon Law Society of America. W myśl zaproponowanego przez

9 Por. J. R. Quinn, The Reform of the Papacy. The Costly Call to Christian Unity, New York I999, S.II7-I23.

ıo Por. B. Sesboüé, Wtadza w Kościele. Autorytet, prawda i wolnośc, tłum. P. Rak, Kraków 2003, s. 244.

II Por. J. Lewandowicz, Wybory biskupów w świetle korespondencji Grzegorza Wielkiego, „Vox Patrum” 3 o (2010) t. 55, s. 396.

I2 Por. Kodeks prawa kanonicznego, przekład polski zatwierdzony przez Konferencję Episkopatu Polski, Poznań I984 [dalej: KPK], kan. 377 § 3 .

I3 Por. kan. 377 § І крк. 
nich rozwiązania dziesięcioosobowe komitety w wakujących diecezjach, składające się z duchownych i świeckich, przy jedynie doradczym głosie metropolity tworzyłyby listę kandydatów. Wybrane osoby byłyby przedstawiane przewodniczącemu konferencji episkopatu, a ten, po aprobacie, wysyłałby je do Rzymu. Biskup Rzymu nie mógłby wybierać spoza przedstawionych przez Kościól lokalny osób. Propozycja ta została odrzucona, choć dziś można by się nad nią znowu pochylić. Komentując powyższą propozycję, Quinn wskazał, że prawdopodobnie skróciłaby ona czas oczekiwania na nowego biskupa $w$ diecezjach. Ponadto wpłynęłaby na uwzględnianie pożądanych kompetencji kandydatów. Według cytowanego hierarchy często głównym warunkiem jest, by nowy biskup gwarantował zachowanie stabilności, w związku z czym przepadają zazwyczaj kandydatury reformatorów, księży będących blisko ludu, zaangażowanych $\mathrm{w}$ inicjatywy oddolne, otwartych na nowe ide ${ }^{\mathrm{It}}$. W konsekwencji cierpi na tym z pewnością pasterski wymiar posługi biskupiej.

\section{RELACJA BISKUPA DO WIERNYCH W DIECEZJI}

Podczas spotkania papieża Franciszka $\mathrm{z}$ wyświęconymi w pierwszym półroczu 2017 roku biskupami padły słowa, które powinny stanowić program dla realizacji ich pasterskiej funkcji. Papież mówił: „Biskup nie jest samowystarczalnym «ojcem-władcą» ani też «samotnym pasterzem», przestraszonym i odizolowanym. Rozeznanie biskupa jest zawsze działaniem wspólnotowym, które nie pomija bogactwa opinii jego prezbiterów i diakonów, Ludu Bożego i tych wszystkich, którzy mogą dać mu swój pożyteczny wkład. W pogodnym dialogu nie obawia się on dzielić $z$ innymi swoim rozeznaniem, czasem nawet je modyfikując. Dzielić się ze współbraćmi w biskupstwie, z którymi zjednoczony jest sakramentalnie, a wtedy rozeznanie staje się kolegialne. Ze swoimi kapłanami, dla których jest gwarantem takiej jedności, jakiej nie narzuca się siłą, ale tworzy się ją z cierpliwością i mądrością rękodzielnika. $Z$ wiernymi świeckimi,

I4 Por. J. R. Quinn, The Reform of the Papacy..., dz. cyt., s.I29-I37. Wedlug Appleby'ego wiele nominacji biskupich w Stanach Zjednoczonych w xx wieku stanowiło romanizację amerykańskiej hierarchii, a nie troskę o zrozumienie specyfiki tamtych wspólnot. Por. R. S. Appleby, Ending as It Began? The American Century and the Americanist Dream, w: The Exercise of the Primacy. Continuing the Dialogue, ed. P. Zagano, T. W. Tilley, New York I998, s. 38n. 
którzy mają «wyczucie» prawdziwej nieomylności wiary w Kościele: oni wiedzą, że Bóg nie ustaje w swojej miłości i nie wypiera się swoich obietnic. Zachęcam was zatem, byście pielęgnowali postawę słuchania, wzrastając $\mathrm{w}$ wolności rezygnowania $\mathrm{z}$ własnego punktu widzenia, kiedy okazuje się on niepełny i niewystarczający, aby przyjąć punkt widzenia Boga"זs.

Kluczem do zrozumienia oczekiwań biskupa Rzymu wydaje się być rozeznawanie woli Bożej w relacji pasterskiej. Franciszek podkreślał konieczność nieustannych konsultacji między ordynariuszem a poszczególnymi grupami wiernych, by w ten sposób zbliżać się do prawdy. Elementem koniecznym takiego rozeznawania jest budowanie bliskich relacji. Można więc powiedzieć, że inwestycja w relacje wewnątrz owczarni jest warunkiem skutecznego pasterzowania. Kiedy rozpatruje się w tej perspektywie punkty sporne i potencjalne zmiany w aktualnej sytuacji eklezjalnej, przychodzą na myśl - poza wspomnianą już kwestią mianowania biskupów - dwie przeszkody, których usunięcie mogłoby ułatwić tworzenie klimatu wzajemnego poznawania się i słuchania: istnienie urzędu biskupów pomocniczych oraz transfery międzydiecezjalne ordynariuszy. Widzę też konieczność zmian w praktyce sprawowania posługi biskupiej na co dzień.

\section{A) IsTNIENIE URZĘDU BISKUPÓW POMOCNICZYCH}

Jeśli pasterz diecezji utożsamiany jest z jej ojcem, niezrozumiałe wydaje się istnienie kilku biskupów w jednej diecezji. Trudno wtedy wytłumaczyć wiernym wyjątkowy, pasterski wymiar tej posługi, ponieważ jest on realizowany przez kilka osób w tym samym stopniu święceń, z jednoczesnym zastrzeżeniem, że nie są oni równi w kompetencjach. Taka sytuacja może czasem sprzyjać procesowi zarządzania, ale w przypadku sufraganów rola biskupa jako pasterza wydaje się być nie do uratowania.

Istnienie biskupów pomocniczych jest problematyczne także z powodów teologicznych: skoro bowiem biskup jest następcą apostołów, to jak w tym kluczu nazwać biskupa pomocniczego? Kolejny argument przemawiający przeciwko aktualnej strukturze episkopatów lokalnych

I5 Franciszek, Przemówienie do uczestników dorocznego spotkania dla wyświęconych w ostatnich miesiqcach biskupów, http://episkopat.pl/papiez-do-nowych-biskupow-duszpasterskie-rozeznanie/ (I5.IO.20I7). Podkreślenia własne. 
pochodzi z historii: w kanonie viII Soboru Nicejskiego zapisano nakaz sprawowania funkcji przez jednego biskupa w jednym mieście ${ }^{\mathrm{r}}$. Problematyczność obserwowanych dziś rozwiązań widać w końcu na polu działalności praktycznej. Wspomniany już Quinn wskazał, że główną odpowiedzialnością obarczony jest i tak tylko jeden biskup, a pozostali korzystają z władzy święceń biskupich przede wszystkim w celu udzielania sakramentu bierzmowania, co takiej władzy wcale nie wymaga ${ }^{17}$. Rozsądnym na wielu polach rozwiązaniem byłoby więc zastąpienie sufraganów wikariuszami generalnymi bez sakry. Ponadto, gdyby nie było biskupów pomocniczych, po wakacie na stanowisku ordynariusza nowy biskup miałby możliwość pełnej wymiany kadry w kuriach diecezjalnych. W takim modelu wyraźnie zaznaczyłaby się funkcja pasterza i jego pomocników, którzy nie są biskupami.

\section{в) Przechodzenie biskupów z Diecezji do DiecezjI}

Bardzo poważnym wyzwaniem dla osób uzasadniających pasterską funkcję biskupa w diecezji jest praktyka przenosin ordynariuszy między stolicami. $Z$ jednej bowiem strony mówi się, że relacja pasterza $z$ diecezją ma głębokie racje teologiczne, porównywane $\mathrm{w}$ średniowieczu $\mathrm{z}$ relacją małżonków, a z drugiej stosunkowo łatwo znajduje się powody do zerwania tej więzi. Obserwując takie „transfery”, trudno uniknąć wrażenia, że stanowisko ordynariusza ma naturę wyłącznie administracyjną, a proces kolejnych nominacji to droga „kościelnej kariery”. praktyka powinna być zakazana. Można znaleźć wiele przykładów takich zmian, w których dostrzegalne są korzyści menadżerskie, ale pasterskie raczej tam nie wybrzmiewają.

I6 Por. Sobór Nicejski I, Kanon VIII, w: Dokumenty soborów powszechnych. Tom I: 325-787, red. A. Baron, H. Pietras, Kraków 2002, s. 34n. Także Sobór Chalcedoński zakazał udzielania święceń bez tytułu, a jeśli są już tacy wyświęceni, to wtedy ich święcenia należy uznać za nieważne. Można w różny sposób próbować obejść ten zapis, nie ulega jednak wątpliwości, że jest on problematyczny dla praktyki mianowania biskupów pomocniczych czy udzielania sakry pracownikom Kurii Rzymskiej. Zob. Sobór Chalcedoński, Kanon VI, w: Dokumenty soborów powszechnych. Tom I: 325-787, dz. cyt., s. 23I.

I7 Por. J. R. Quinn, The Reform of the Papacy..., dz. cyt., s.I37-I39.

I8 Por. J. R. Quinn, The Reform of the Papacy..., dz. cyt., s. I29-I37. 


\section{c) Komunikacja biskupów z Diecezjanami}

Z punktu widzenia oczekiwań wiernych i możliwości ich realnej współodpowiedzialności za Kościół lokalny można zastanawiać się nad modyfikacjami w pasterskich inicjatywach praktycznych. Wśród najczęściej wymienianych dziś oczekiwań wiernych wobec osób prowadzących ich drogami wiary znajdują się: potrzeba konsultacji przy sprawowaniu władzy, odmowa przyjmowania treści tylko na mocy autorytetu, potrzeba otrzymywania merytorycznych uzasadnień dla stawianych wymagań. Coraz częściej wśród wiernych mamy do czynienia $\mathrm{z}$ religijnością rozumną i krytyczną, wynikającą między innymi z łatwiejszego dostępu do treści teologicznych. Wierni oczekują więc od biskupów raczej dyskursu, w którym dominowałby klimat zaproszenia niż katechizacji w formie prezentacji zobowiązań, a w miejsce pytania o przedmiot wiary stawiają te o sens jej wyznawania. Szukając optymalnych pasterzy, wierni wybierają nie tyle nauczycieli wykładających w autorytarny sposób prawowierną naukę, ile przyjaciól, którzy podejmują dialog i towarzyszą na drogach życia ${ }^{\text {19. }}$. Można zapytać, w jakim stopniu aktualne wizytacje biskupie $\mathrm{i}$ listy pasterskie wpisują się w taką wizję? Bardzo często te pierwsze są świętem w parafii, a nie realną konfrontacją, natomiast słowa biskupów $\mathrm{z}$ ambon odpowiedzią na pytania, które nie stanowią dylematów większości wiernych, a ponadto są wyrażone w języku dalekim od sposobów codziennej komunikacji. W wywiadzie z Dominikiem Woltonem, papież Franciszek stwierdził: „Przyczyną każdej sztywności jest niezdolność do komunikacji. A ja zawsze uważałem [...] Weźmy tych sztywnych kapłanów, którzy boją się komunikacji, weźmy sztywnych polityków [...] To jest jakaś postać fundamentalizmu”º.

Szukając propozycji zmian na polu praktycznym, można pomyśleć o szerszym uwzględnianiu narzędzi informatycznych i statystycznych w celu wydobycia realnych problemów współczesnych społeczeństw i uwzględniania ich przy redagowaniu listów odczytywanych w parafiach. Można też zlecać ich napisanie osobom, których warsztat retoryczny zapewnia lepsze dotarcie z prezentowanymi treściami do odbior-

I9 Szerszej analizy tych kontekstów dokonałem w książce Nowa wizja zarządzania Kościotem, dz. cyt., s. 9-23.

20 Franciszek, D. Wolton, Otwieranie drzwi. Rozmowy o Kościele i świecie, tłum. M. Chojnacki, Kraków 2018, s. 390. 
ców $\mathrm{w}^{2 \mathrm{I}}-\mathrm{w}$ wyselekcjonowaniu ekspertów powinna pomóc obserwacja frekwencji na prowadzonych przez nich rekolekcjach i nakłady książek popularyzujących teologię. W celu konfrontacji z aktualnymi pytaniami wiernych konieczne wydaje się wprowadzenie systemu ankiet, zespołów doradzających, wirtualnych i realnych forów wymiany myśli. Wypracowanie skutecznych narzędzi w tym zakresie wymaga intensywniejszego korzystania $z$ nowych technologii, ale przede wszystkim wzbudzenia w wiernych poczucia, że ich głos może mieć wpływ na rzeczywistość diecezjalną, jest słyszany i spotyka się z reakcją pasterzy.

Na początku artykułu założyłem, że spróbuję odpowiedzieć na pytanie, gdzie pasterski wymiar posługi biskupiej zszedł na dalszy plan i jak można by to zmienić. Można wskazać trzy drogi takich modyfikacji: odejście od praktyk mianowania biskupów w miejscach, gdzie potrzeba jedynie zarządców, decentralizację kompetencji w strukturach kościelnych oraz poprawę komunikacji między wiernymi i biskupami.

Postawione przede mną zadanie poszukiwania punktów spornych i perspektyw zmian w posłudze biskupiej rodzi przynajmniej jedną poważną wątpliwość. W tytułowej alternatywie znalazła się sugestia zgodna zresztą z teologią episkopatu - że biskup powinien być przede wszystkim pasterzem, a w drugiej kolejności zarządcą. Pisząc tekst, zastanawiałem się, czy w aktualnej sytuacji społecznej i eklezjalnej taka teologia jest do utrzymania. Można bowiem postawić hipotezę, że wraz z rozwojem chrześcijaństwa i zwiększeniem liczebności wiernych świeckich i duchownych funkcja pasterska zwierzchników diecezji musiała zostać zmarginalizowana na rzecz kompetencji organizacyjnych i zarządczych. W konsekwencji pasterzowanie biorą na barki księża pracujący na parafiach, a ich zwierzchnicy zajmują się głównie koordynacją tych działań i nadzorem. Jeśli taka diagnoza jest prawdziwa, to może nie powinno się krytykować biskupów za brak troski pasterskiej, ale rozliczać ich z odpowiedniego zarządzania kapitałem ludzkim, funkcji menadżerskich i umiejętności organizacyjnych? Tylko co wtedy z wynikającym z Biblii i Tradycji profilem episkopatu? Czy można traktować

2I „Właśnie odnowa form wyrazu staje się konieczna, aby można było przekazywać współczesnemu człowiekowi ewangeliczne orędzie w jego niezmiennym sensie” (EG 4I). 
wszystkie te zapisy historii jako elementy kontekstualne i odłożyć na półkę $\mathrm{z}$ literaturą przedawnioną?

Jeśli ten tekst ma być próbą poszukiwania kompromisu między wiernością Tradycji a wiarygodnością wobec współczesności, widzę przynajmniej jedną możliwość, by uniknąć zasygnalizowanych problemów z teologiczną hermeneutyką ciągłości. Wymaga ona jednak szerokich modyfikacji strukturalnych. Można by zmniejszyć obszary diecezji do poziomu obecnych dekanatów i oddzielić je od rozbudowanych struktur administracyjnych - kurie pozostawić jako centra zarządzające na poziomie obecnych diecezji albo nawet metropolii, a na ich czele postawić wykształconych zarządców, a nie biskupów. Wtedy biskupi byliby odciążeni z wysiłków organizacyjnych, mogliby funkcjonować bliżej ludu Bożego i bliżej księży współpracowników, mogliby skupić się na zadaniach pasterskich i budować zdecydowanie bliższe relacje interpersonalne i ewangelizacyjne, a same kurie prawdopodobnie funkcjonowałyby jeszcze sprawniej i bardziej profesjonalnie.

\section{BiBLIOGRAFIA}

Appleby R. S., Ending as It Began? The American Century and the Americanist Dream, w: The Exercise of the Primacy. Continuing the Dialogue, eds. P. Zagano, T. W. Tilley, New York 1998, s. 29-45.

Franciszek, Amoris laetitia, https://w2.vatican.va/content/francesco/pl/apost_ exhortations/documents/papa-francesco_esortazione-ap_20160319_amoris-laetitia.html (30.10.2017).

Franciszek, Evangelii gaudium, https://w2.vatican.va/content/francesco/pl/ apost_exhortations/documents/papa-francesco_esortazione-ap_20I3II24_ evangelii-gaudium.html (30.10.2017).

Franciszek, Magnum principium, http://press.vatican.va/content/salastampa/en/ bollettino/pubblico/2017/og/og/170909a.html (30.10.2017).

Franciszek, Przemówienie do uczestników dorocznego spotkania dla wyświęconych w ostatnich miesiąach biskupórw, http://episkopat.pl/papiez-do-nowych-biskupow-duszpasterskie-rozeznanie/ (I5.10.2017).

Franciszek, Wolton D., Otwieranie drzwi. Rozmowy o Kościele i świecie, tłum. M. Chojnacki, Kraków 2018.

Jan Paweł II, Ut Unum Sint, https://opoka.org.pl/biblioteka/W/wp/jan_pawel_ii/encykliki/ut_unum_2.html\#m3 (30.10.2017). 
Kard. Sarah: ttumaczenia ksiag liturgicznych nadal muszq być zatwierdzone przez Rzym, https://www.deon.pl/religia/kosciol-i-swiat/z-zycia-kosciola/ art,31997,kard-sarah-tlumaczenia-ksiag-liturgicznych-nadal-musza-byc-zatwierdzone-przez-rzym.html?utm_source=deon\&utm_medium $=$ link_ artykul (30.10.2017).

Kodeks prawa kanonicznego, przekład polski zatwierdzony przez Konferencję Episkopatu Polski, Poznań 1984.

Lewandowicz J., Wybory biskupów w świetle korespondencji Grzegorza Wielkiego, „Vox Patrum” 30 (2010) t. 55, s. 395-409.

Papież poprawia kard. Saraha. Zmiany liturgiczne sa gtębsze niż wskazywat hierarcha, https://www.deon.pl/religia/serwis-papieski/aktualnosci-papieskie/ art,63or,papiez-poprawia-kard-saraha-zmiany-liturgiczne-sa-glebsze-niz-wskazywal-hierarcha.html (30.10.2017).

Quinn J. R., The Reform of the Papacy. The Costly Call to Christian Unity, New York 1999.

Sesboüé B., Wtadza w Kościele. Autorytet, prawda i wolność, tlum. P. Rak, Kraków 2003.

Sobór Chalcedoński, Kanon VI, w: Dokumenty soborów powszechnych. Tom I: 325-787, red. A. Baron, H. Pietras, Kraków 2002, s. 231.

Sobór Nicejski I, Kanon VIII, w: Dokumenty soborów powszechnych. Tom I:325-787, red. A. Baron, H. Pietras, Kraków 2002, s. 34n.

Wąsek D. Nowa wizja zarzqdzania Kościotem, Kraków 2014. 